\title{
Bovine respiratory syncytial virus seroprevalence and risk factors in non- vaccinated dairy cattle herds in Brazil
}

\author{
Ingrid Bortolin Affonso Lux Hoppe ${ }^{1 *}$ (D), Andréa Souza Ramos de Medeiros ${ }^{1}$, Clarice Weis Arns ${ }^{2}$ \\ and Samir Issa Samara ${ }^{1}$
}

\begin{abstract}
Background: The cattle industry is one of the most important Brazilian agribusiness sectors and is a strong contributor to the national economy. Annually about 44.6 million calves are bred, which makes the optimal management of these animals extremely important. Several diseases can affect the initial stages of the bovine production chain, being the bovine respiratory syncytial virus (BRSV) one of the most relevant pathogens. This study aimed to characterize the epidemiology of BRSV infection in dairy cattle herds of São Paulo State, Brazil, using serological and risk factors analyses. For that, 1243 blood samples were collected of animals from 26 farms and a questionnaire about possible risk factors for BRSV prevalence was performed. The obtained blood sera were analyzed using virus neutralization test (VNT).

Results: VNT results showed high BRSV prevalence in dairy cattle herds, reaching $79.5 \%$ of seropositivity. The BRSV seroprevalence among studied farms ranged from 40 to 100\%. The analysis of risk factors indicated that the age group and the occurrence of coinfection with bovine herpesvirus 1 (BoHV-1) and bovine viral diarrhea virus 1 (BVDV-1) should be associated with a higher prevalence of BRSV, while natural suckling was considered a protective factor.

Conclusions: The study showed that adult animals over 1 year old are an important risk factor for the high seroprevalence of BRSV in herds. The high BRSV prevalence associated with BoHV-1 and BVDV-1 suggests that biosecurity measures should be applied in order to reduce viral dissemination. Additionally, the natural suckling may be an important management to protect calves from high BRSV seroprevalence.
\end{abstract}

Keywords: Bovine respiratory syncytial virus, Seroprevalence, Risk factors, Dairy cattle herds

\section{Background}

Bovine respiratory syncytial virus (BRSV) is an economically significant pathogen in cattle production [1], as it is one of the most important causes of lower respiratory tract infections in calves [2]. In dairy cattle, BRSV infection usually occurs in young calves aged between 2 weeks and 9 months [3]. Adult animals with subclinical infection are the main source of infection, since reinfections are common in the herds $[1,4,5]$.

\footnotetext{
* Correspondence: ibaffonso@gmail.com

'Faculdade de Ciências Agrárias e Veterinárias (FCAV), Departamento de Medicina Veterinária Preventiva e Reprodução Animal, Univ Estadual Paulista - UNESP, Via de Acesso Prof. Paulo Donato Castellane, km 05, Jaboticabal, São Paulo CEP: 14.884-900, Brazil

Full list of author information is available at the end of the article
}

BRSV, bovine herpesvirus 1 (BoHV-1), bovine viral diarrhea virus (BVDV) and bovine parainfluenza type-3 (PI-3) are considered primary agents involved in the bovine respiratory complex. Additionally, secondary infection by Pasteurella multocida, Histophilus somni and mycoplasmas contribute to the aggravation of the disease [6]. Clinical signs are characterized by respiratory symptoms, initially with moderated intensity, such as nasal and ocular discharges which can be aggravated leading to pneumonia. However, mainly in calves, an acute and severe onset is also observed, due to maternal antibodies not effectively protect against BRSV infection [3].

Considering the high prevalence of the disease, several studies determined risk factors involved in the 
epidemiology of BRSV. In Europe, risk factors were mainly attributed to herd size, herd density, purchasing of new animals, geographic location of the farms, herd type and concomitant BVDV infection [7-11]. Similar studies have also been performed in some Latin American countries and they showed that most of the animals probably have already been exposed to the virus with consequent high BRSV prevalence in cattle herds. In these countries, herd size, age group, presence of bordering farms, herd type and geographic location of the farms were the main risk factors associated with BRSV infection [12-16].

In Brazil, BRSV was first diagnosed in calves in the state of Rio Grande do Sul [17] and some studies have shown that BRSV infection is widespread in Southern and Southeastern Brazil, with high serological prevalence rates [18-20]. Nevertheless, research has not been conducted in order to verify possible risk factors involved in BRSV epidemiology. Due to this, the current study aimed to determine antibody prevalence against BRSV and investigate some risk factors associated with BRSV seroprevalence in herds of an important milk producing region in São Paulo State, Brazil.

\section{Methods}

\section{Study area and sample collection}

The study was performed on 26 dairy cattle herds in 12 municipalities in the Northern region of the São Paulo State, Southeastern Brazil. This region produces about 10 million liters of milk annually [21]. The evaluated herds had between 6 and 150 animals and no animals were vaccinated against the pathogens associated with respiratory diseases. The farms were located in a region classified as Aw by the climatic classification of Koeppen, characterized by dry winter with average temperature higher than $18{ }^{\circ} \mathrm{C}$ in the coldest month and precipitation below $60 \mathrm{~mm}$ in the driest month. The altitude of these areas was 440 to $617 \mathrm{~m}$ above sea level [22].

Sampling of each farm was calculated [23] with an expected BRSV prevalence of $80 \%$ [19] with acceptable error of $5 \%$ and confidence level of $95 \%$. After setting the number of samples, bovines of all categories and age group were randomly selected. According to the management adopted in the herds, the age group was defined as $\leq 12$ months old "calf" and $>12$ months old "adult". In some farms, the number of samples collected was higher than that suggested by the mathematical calculation, once it was also used for serodiagnosis of BoHV-1 and BVDV-1. On farms with a small herd size, up to 30 animals, all of them were sampled.

The samples from 1243 animals were collected from April 2012 to June 2012 as shown in Table 1. Blood samples were collected by jugular or coccygeal vein puncture using disposable needles and vacuum tubes. Samples
Table 1 Total of blood samples collected in 26 dairy cattle herds in the Northern region of the São Paulo State, Southeastern Brazil

\begin{tabular}{|c|c|c|c|c|}
\hline \multirow{2}{*}{$\begin{array}{l}\text { Dairy } \\
\text { cattle } \\
\text { herds }\end{array}$} & \multirow{2}{*}{$\begin{array}{l}\text { Total } \\
\text { number } \\
\text { of } \\
\text { animals }\end{array}$} & \multicolumn{2}{|c|}{ Number of blood samples } & \multirow{2}{*}{$\begin{array}{l}\text { Total of } \\
\text { samples }\end{array}$} \\
\hline & & Adult & Calf & \\
\hline 1 & 75 & 47 & 25 & 72 \\
\hline 2 & 38 & 21 & 14 & 35 \\
\hline 3 & 88 & 50 & 23 & 73 \\
\hline 4 & 55 & 31 & 20 & 51 \\
\hline 5 & 50 & 25 & 19 & 44 \\
\hline 6 & 120 & 41 & 25 & 66 \\
\hline 7 & 7 & 5 & 2 & 7 \\
\hline 8 & 9 & 9 & 0 & 9 \\
\hline 9 & 120 & 85 & 16 & 101 \\
\hline 10 & 150 & 81 & 37 & 118 \\
\hline 11 & 36 & 24 & 12 & 36 \\
\hline 12 & 120 & 83 & 36 & 119 \\
\hline 13 & 80 & 59 & 18 & 77 \\
\hline 14 & 40 & 28 & 3 & 31 \\
\hline 15 & 40 & 26 & 9 & 35 \\
\hline 16 & 15 & 10 & 5 & 15 \\
\hline 17 & 26 & 20 & 6 & 26 \\
\hline 18 & 15 & 12 & 3 & 15 \\
\hline 19 & 60 & 37 & 13 & 50 \\
\hline 20 & 100 & 61 & 27 & 88 \\
\hline 21 & 16 & 11 & 5 & 16 \\
\hline 22 & 6 & 6 & 0 & 6 \\
\hline 23 & 52 & 37 & 11 & 48 \\
\hline 24 & 22 & 19 & 3 & 22 \\
\hline 25 & 62 & 44 & 17 & 61 \\
\hline 26 & 22 & 19 & 3 & 22 \\
\hline Total & & 891 & 352 & 1243 \\
\hline
\end{tabular}

remained at room temperature for $1 \mathrm{~h}$ for coagulation and after being transported refrigerated to the laboratory, they were centrifuged at $1080 \times g$ for $10 \mathrm{~min}$ to obtain the sera. The sera were aliquoted in $1.5 \mathrm{~mL}$ identified microtubes that were stored in freezer at $20{ }^{\circ} \mathrm{C}$ until analyses.

\section{Virus neutralization test}

The presence of antibodies to BRSV was tested by virus neutralization test (VNT). Serum samples were thawed, inactivated in water bath at $56{ }^{\circ} \mathrm{C}$ for $30 \mathrm{~min}$, and diluted in duplicates from 1:2 to 1:1024 in 96-well microplates with $50 \mu \mathrm{L}$ of $200 \mathrm{TCID}_{50}$ BRSV suspended in Eagle's minimum essential medium (DIFCO E-MEM ${ }^{\circ}$ ). The viral strain was previously titrated [24]. Following 
incubation at $37{ }^{\circ} \mathrm{C}$ in $5 \% \mathrm{CO}_{2}$ atmosphere for $1 \mathrm{~h}$, $50 \mu \mathrm{L}$ of Madin \& Darby Bovine Kidney (MDBK) cells suspension, in E-MEM and 10\% bovine fetal serum solution were added to the wells. Then, the plates were re-incubated in similar conditions for $96 \mathrm{~h}$. Each test included a back titration and cell culture control. Samples were positive when cytopathic effect was inhibited at 1:2 dilution, and the titration was expressed as the inverse of the dilution, as geometric mean.

\section{Risk factors}

During the sample collection, a questionnaire was administered to the owner or manager of each farm with the purpose of identifying potential risk factors related to epidemiology of BRSV. Thus, the questionnaire was designed according to data of risk factors described in the literature $[8,10,15,16]$ in addition to the information of the management adopted in dairy farms of São Paulo State. The variables explored were: herd size $(\leq 75$, $>75$ animals), herd density ( $\leq 5,>5$ animals/hectare), age group ( $\leq 12$ months old "calf", > 12 months old "adult"), breed (Holstein, mixed), type of reproduction (natural mating, artificial insemination), purchase of animals (last 6 months: yes, no), cleaning of facilities (often, rarely), historical of respiratory disease (last 6 months: yes, no), quarantine (yes, no), abortions (yes, no), BoHV-1 infection (serodiagnosis: yes, no), BVDV-1 infection (serodiagnosis: yes, no), type of calves housing (individual, collective), type of calves feeding (natural suckling, artificial), presence of others domestic animals (yes, no), presence of wild ruminant animals (yes, no).

The variables "herd size" and "herd density" were based on the average data; "age group" was defined from the management adopted on the farms; "quarantine" refers to the isolation of purchased animals before adding them to the herd. The serodiagnosis of BoHV-1 and BVDV-1 was performed at the same time as BRSV (unpublished data). The variables "disinfection of the umbilical cord" and "colostrum feeding" were not analyzed because these practices were applied in all dairy farms visited. Additionally, the data related to climatic classification and altitude were not included in the analysis because they were similar in all 26 farms.

\section{Statistical analysis}

The chi-square tests were employed to compare the BRSV, BoHV-1 and BVDV-1 seropositivity and also with "age group". Fisher's exact test was used to compare BRSV status according to the expected prevalence of $80 \%$ ( $\geq 80 \%$, "high"; $<80 \%$, "low") and the other variables. Only the variables with $p<0,2$ (two-tailed Fisher) were analyzed by a logistic regression model. The analyses were performed using the Epi Info ${ }^{\text {tw }}$ program v. 7.0.

\section{Results}

Serum samples from 1243 animals belonging to 26 dairy cattle herds were taken and tested by VNT, in which 988 (79.5\%) were seropositive to BRSV. Regarding the age group, $87 \%$ (767/ 891) of the serum samples were positives for adult animals while the prevalence rate in calves was $62.8 \%(352 / 221)$. Antibodies to BRSV were detected in all cattle herds, with prevalence rates ranging from 40 to $100 \%$. The mean antibody titers for adult animals was 2 to 512, and for calves, 2 to 32. Therefore, prevalence of BRSV both in herds and animals was considered high.

The chi-square test showed association of BRSV seropositivity with "age group" and animals tested seropositives to BoHV-1 and BVDV-1 (Table 2). Nevertheless, the Fisher's exact test only detected statistical difference with the variable "type of calves feeding" (Table 3). In this case, the relative risk (RR) value was less than one, i.e., the factor "natural suckling" was considered protective. Logistic regression (values of $p<0.2$, two-tailed Fisher) did not show significant results, suggesting that the variables analyzed were not risk factors for the high seroprevalence of BRSV in the studied population.

\section{Discussion}

This is the first epidemiological study to assess risk factors for BRSV seroprevalence carried out in Brazil. Even though BRSV prevalence of $79.5 \%$ in the animals sampled was similar to that estimated, the prevalence in adult animals was higher than that expected, reaching $87 \%$ of samples. In calves, the seroprevalence was lower than that found in adult animals $(62.8 \%)$ and could be even lower once VNT does not allow the distinction between antibodies from colostrum and natural infection. Thus, this study demonstrated that the prevalence of BRSV antibodies was higher in adult animals, as previously reported in other countries $[13,16]$.

Adult animals are associated with high seroprevalence of BRSV as consequence of a repeated exposure to the virus infection throughout their life and possibility of reinfections. Similarly, the highest antibody titers were associated with non-vaccinated adult cattle, probably due to the exposure to successive viral reinfections, which results in a booster effect on antibody titers [25]. Other factor related to high antibody titers is recent BRSV infections, which can be confirmed only by paired serology, antibody screening in calves after the period of colostral antibody detection or viral detection by direct methods. As respiratory disease was not reported in half of the herds studied, it is indicative that BRSV infection can be subclinical. This is consistent with previous reports [2]. Herds can remain free of clinical BRSV infection for many years even in areas of high prevalence of the virus [26]. 
Table 2 Risk factors associated with BRSV in 1243 animals from 26 dairy cattle herds in São Paulo State, Brazil

\begin{tabular}{|c|c|c|c|c|c|c|c|}
\hline \multirow[t]{2}{*}{ Factor } & & \multicolumn{2}{|l|}{ BRSV } & \multirow{2}{*}{$\begin{array}{l}\text { Relative } \\
\text { risk (RR) }\end{array}$} & \multicolumn{2}{|c|}{ Confidence interval (CI) (95\%) } & \multirow[t]{2}{*}{$p$ value } \\
\hline & & Positive & $\overline{\text { Negative }}$ & & Limit inferior & Limit superior & \\
\hline \multirow[t]{2}{*}{ Age group } & $>12$ months (adult) & 775 & 116 & 1.44 & 1.32 & 1.57 & $<0.0001$ \\
\hline & $\leq 12$ months (calf) & 213 & 139 & & & & \\
\hline \multirow[t]{2}{*}{$\mathrm{BoHV}-1$} & Seropositive & 565 & 85 & 1.22 & 1.15 & 1.29 & $<0.0001$ \\
\hline & Seronegative & 423 & 170 & & & & \\
\hline \multirow[t]{2}{*}{ BVDV-1 } & Seropositive & 298 & 33 & 1.19 & 1.13 & 1.25 & $<0.0001$ \\
\hline & Seronegative & 690 & 222 & & & & \\
\hline
\end{tabular}

The presence of other pathogens is also associated with the prevalence of BRSV $[8,11,14,16]$. This information explains the association of BRSV serological prevalence with the prevalences of BoHV-1 and BVDV-1. The infection by these viral agents is also reported in Brazilian herds, with high prevalences [27, 28].
BVDV infection can cause impairment of the animal's immune function and thereby decrease resistance to other infections [8]. The synergistic effects of BVDV with other respiratory pathogens have been observed $[29,30]$. Thus, health status of the herds may also be affected indirectly by BVDV control measures [8].

Table 3 Risk factors associated with high and low bovine respiratory syncytial virus prevalence at herd level in 26 dairy cattle herds in São Paulo State, Brazil

\begin{tabular}{|c|c|c|c|c|c|c|c|}
\hline \multirow[t]{2}{*}{ Factor } & \multirow[t]{2}{*}{ Condition } & \multicolumn{2}{|c|}{ BRSV status } & \multirow[t]{2}{*}{$\mathrm{RR}$} & \multicolumn{2}{|l|}{$\mathrm{Cl}(95 \%)$} & \multirow{2}{*}{$\begin{array}{l}p \\
\text { value }\end{array}$} \\
\hline & & High & $\overline{\text { Low }}$ & & Limit inferior & Limit Superior & \\
\hline \multirow[t]{2}{*}{ Herd size (> 75 animals) } & Yes & 3 & 2 & 1.40 & 0.59 & 3.34 & 0.422 \\
\hline & No & 9 & 12 & & & & \\
\hline \multirow[t]{2}{*}{ Herd density (> 5 animals/ha) } & Yes & 5 & 4 & 1.34 & 0.60 & 3.05 & 0.387 \\
\hline & No & 7 & 10 & & & & \\
\hline \multirow[t]{2}{*}{ Breed (Holstein) } & Yes & 7 & 7 & 1.20 & 0.51 & 2.81 & 0.488 \\
\hline & No & 5 & 7 & & & & \\
\hline \multirow[t]{2}{*}{ Type of reproduction (natural mating) } & Yes & 2 & 8 & 0.32 & 0.09 & 1.17 & 0.420 \\
\hline & No & 10 & 6 & & & & \\
\hline \multirow[t]{2}{*}{ Purchasing of animals (last six months) } & Yes & 6 & 10 & 0.63 & 0.28 & 1.41 & 0.237 \\
\hline & No & 6 & 4 & & & & \\
\hline \multirow[t]{2}{*}{ Cleaning of facilities (rarely) } & Yes & 7 & 9 & 0.88 & 0.38 & 2.01 & 0.536 \\
\hline & No & 5 & 5 & & & & \\
\hline \multirow[t]{2}{*}{ Historical of respiratory disease (last six months) } & Yes & 7 & 6 & 1.40 & 0.60 & 3.28 & 0.347 \\
\hline & No & 5 & 8 & & & & \\
\hline \multirow[t]{2}{*}{ Quarantine (absence) } & Yes & 10 & 11 & 1.19 & 0.37 & 3.81 & 0.578 \\
\hline & No & 2 & 3 & & & & \\
\hline \multirow[t]{2}{*}{ Abortions } & Yes & 5 & 6 & 0.97 & 0.42 & 2.26 & 0.632 \\
\hline & No & 7 & 8 & & & & \\
\hline \multirow[t]{2}{*}{ Type of calves housing (collective) } & Yes & 9 & 14 & 0.39 & 0.24 & 0.65 & 0.085 \\
\hline & No & 3 & 0 & & & & \\
\hline \multirow[t]{2}{*}{ Type of calves feeding (natural suckling) } & Yes & 3 & 10 & 0.33 & 0.12 & 0.96 & 0.023 \\
\hline & No & 9 & 4 & & & & \\
\hline \multirow[t]{2}{*}{ Presence of others domestic animals } & Yes & 11 & 13 & 0.92 & 0.21 & 3.92 & 0.720 \\
\hline & No & 1 & 1 & & & & \\
\hline \multirow[t]{2}{*}{ Presence of wild ruminant animals } & Yes & 5 & 9 & 0.61 & 0.26 & 1.43 & 0.224 \\
\hline & No & 7 & 5 & & & & \\
\hline
\end{tabular}


Dairy cattle herds in São Paulo State usually have poor biosecurity measures, such as the lack of quarantine of newly purchased animals, lack of diagnosis of respiratory diseases (particularly for BRSV) and vaccination is rarely performed against these viruses. Therefore, we hypothesized that risk factors for the seroprevalence of BoHV-1, BVDV-1 and BRSV in the studied population likely to overlap.

Despite the logistic regression not confirming "type of calves feeding" variable as a risk factor for high prevalence of BRSV, the Fisher's exact test detected "natural suckling" as a protective factor. "Natural suckling" would be important as it may be able to reduce the risk of calves becoming infected by BRSV. Weaning can be stressful and results in impaired immune function, which may further exacerbate a BRSV exposure. Suckling reduces the occurrence of diarrhea, prevents the abnormal behavior of cross-suckling of other calves and improves animal health [31, 32]. Prior to the current study there have been no report about "natural suckling" and its relationship with BRSV seroprevalence or its role as a protective factor, therefore, based on the results presented, it has the potential to decrease seroprevalence to BRSV.

Similarities were observed among the results found at the present study and those previously obtained by others conducted in Brazil [18-20]. In Latin America countries, equivalents prevalences of BRSV have also been reported [12, 14-16], as well as difficulties in detecting the risk factors involved in the dissemination of the agent, even using different forms of sampling and analyzing a considerable number of variables. Thus, the dynamics of infection may differ even in a particular country or geographic area [26].

The high serological prevalence of BRSV found in this study shows the importance to know more about this infection since it is not considered important in the country, mainly due to the lack of diagnosis. The awareness of the risk factors involved in the BRSV dissemination can allow understanding its mechanisms, even though, as in other studies, these factors were not very clear. Thereby, further studies as a complement to the current one should be performed until concrete information has been found.

\section{Conclusions}

Adult animals over 1 year old can present high seroprevalences of BRSV and are an important risk factor for the virus maintenance in herds. Additionally, the concomitant seroprevalence of BoHV-1 and BVDV-1 leads us to suggest that biosecurity measures to reduce viral dissemination could be applied. Non-stressful management, like keeping calves with their mothers promoting natural suckling, may constitute a practical management strategy to reduce the seroprevalence of BRSV in Brazilian dairy herds.

\section{Abbreviations}

BoHV-1: Bovine herpesvirus type-1; BRSV: Bovine respiratory syncytial virus; BVDV: Bovine viral diarrhea virus; Cl: Confidence interval; MDBK: Madin \& Darby Bovine Kidney; Pl-3: Bovine parainfluenza type-3; RR: Relative risk; VNT: virus neutralization test

\section{Acknowledgments}

The authors thank Coordenadoria de Assistência Técnica Integral (CATI/ SAASP) for providing the dairy cattle herds for the study, Dr. Estevam G. Lux Hoppe and Andressa de Souza Pollo for assistance with manuscript revision.

\section{Funding}

This work was supported by Fundação de Amparo à Pesquisa do Estado de São Paulo, FAPESP (financial grant 2010/15912-7 and doctoral scholarship 2010/06950-2).

\section{Availability of data and materials}

The datasets analyzed within the current study are available from the corresponding author upon request.

\section{Authors' contributions}

IBALH and ASRM performed the experiment. IBALH analyzed the data and prepared the manuscript. IBALH, CWA and SIS designed the study and revised the manuscript. All authors read and approved the final manuscript.

\section{Ethics approval and consent to participate}

The work is in accordance with ethical principles in animal experimentation, adopted by the Brazilian Code of Experimentation (COBEA) and approved by the Ethics Committee on Animal Use (CEUA). Protocol 027713/10.

\section{Consent for publication}

Not applicable.

\section{Competing interests}

The authors declare that they have no competing interests.

\section{Publisher's Note}

Springer Nature remains neutral with regard to jurisdictional claims in published maps and institutional affiliations.

\section{Author details}

${ }^{1}$ Faculdade de Ciências Agrárias e Veterinárias (FCAV), Departamento de Medicina Veterinária Preventiva e Reprodução Animal, Univ Estadual Paulista - UNESP, Via de Acesso Prof. Paulo Donato Castellane, km 05, Jaboticabal, São Paulo CEP: 14.884-900, Brazil. ${ }^{2}$ Instituto de Biologia, Universidade Estadual de Campinas - UNICAMP, Cidade Universitária, Caixa-postal: 6109, Campinas, São Paulo CEP: 13.083-970, Brazil.

Received: 17 May 2017 Accepted: 19 June 2018

Published online: 27 June 2018

References

1. Baker JC, Frey M. Bovine respiratory syncytial virus. Vet Clin North Am Food Anim Pract. 1985:1:259-72.

2. Larsen LE. Bovine respiratory syncytial virus (BRSV): a review. Acta Vet Scand. 2000;41:1-24

3. Baker JC, Ames TR, Belknap EB, Dubovi EJ, Bryson DG, Kelling CLBRSV. (Bovine respiratory syncytial virus) infection: its pathogenesis, diagnosis, prevention and treatment. Vet Med. 1993:88:880-906.

4. Baker JC, Ames TR, Markham RJF. Seroepizootiologic study of bovine respiratory syncytial virus in a dairy herd. Am J Vet Res. 1986;47:240-5.

5. Stott EJ, Taylor G. Respiratory syncytial virus: brief review. Arch Virol. 1985;84:1-52.

6. Juaréz F, Trigo F, Chávez G, Vargas R. Identificación de agentes virales por inmunohistoquímica en enfermedades respiratórias de bovinos en corral de engorda. Vet Mexico. 2003;34:1-12. 
7. Elvander M. Severe respiratory disease in dairy cows caused by infection with bovine respiratory syncytial virus. Vet Rec. 1996;138:101-5.

8. Luzzago C, Bronzo V, Salvetti S, Frigerio M, Ferrari N. Bovine respiratory syncytial virus seroprevalence and risk factors in endemic dairy cattle herds. Vet Res Commun. 2010;34:19-24.

9. Norstöm M, Skjerve E, Jarp J. Risk factors for epidemic respiratory disease in Norwegian cattle herds. Prev Vet Med. 2000;44:87-96.

10. Ohlson A, Heuer C, Lockhart C, Travén M, Emanuelson U, Alenius S. Risk factors for seropositivity to bovine coronavirus and bovine respiratory syncytial virus in dairy herds. Vet Rec. 2010;167:201-6.

11. Yesilbag K, Güngör B. Seroprevalence of bovine respiratory viruses in NorthWestern Turkey. Trop Anim Health Prod. 2008;40:55-60.

12. Costa M, García L, Yunus AS, Rockemann DD, Samal SK, Cristina J. Bovine respiratory syncytial virus: first serological evidence in Uruguay. Vet Res. 2000;31:241-6

13. Figueroa-Chávez D, Segura-Correa JC, García-Márquez LJ, Pescador-Rubio A, Valdivia-Flores AG. Detection on antibodies and risk factors for infection with bovine respiratory syncytial virus and parainfluenza virus 3 in dual purpose farms in Colima, Mexico. Trop Anim Health Prod. 2012;44:1417-21.

14. Obando RC, Hidalgo M, Merza M, Montoya A, Klingeborn B, Moreno LJ. Seroprevalence to bovine virus diarrhoea virus and other viruses of the bovine respiratory complex in Venezuela (Apure state). Prev Vet Med. 1999; 41:271-8.

15. Saa LR, Perea A, Jara DV, Arenas AJ, Garcia-Bocanegra I, Borge C, Carbonero A. Prevalence of and risk factors for bovine respiratory syncytial virus (BRSV) infection in non-vaccinated dairy and dual-purpose cattle herds in Ecuador. Trop Anim Health Prod. 2012;44:1423-7.

16. Solís-Calderón JJ, Segura-Correa JC, Aguilar-Romero F, Segura-Correa VM. Detection of antibodies and risk factors for infections with bovine respiratory syncytial vírus and parainfluenza virus-3 in beef cattle of Yucatan, Mexico. Prev Vet Med. 2007;82:102-10.

17. Gonçalvez IPD, Simanke AT, Jost HC, Hötzel I, Dal Soglio A, Moojen V. Detection of bovine respiratory syncytial virus in calves of Rio Grande do Sul, Brazil. Cienc Rural. 1993;23:389-90.

18. Affonso IB, Gatti SP, Alexandrino B, Oliveira MC, Medeiros ASR, Buzinaro MG, Samara SI. Detection of antibodies against bovine respiratory syncytial virus (BRSV) in dairy cattle with different prevalences of bovine herpesvirus type 1 (BHV-1) in São Paulo State, Brazil. Semin: Cien Agrar. 2011;32:295-300.

19. Arns CW. Vírus respiratório sincicial dos bovinos (BRSV): Situação no Brasil. In: $1^{\circ}$ Simpósio Pfizer sobre doenças infecciosas e vacinas para bovinos; 1996; Guarulhos, Brasil.

20. Campalans J, Arns CW. Serological evidence of bovine respiratory syncytial virus in Brazil. Virus Rev Res. 1997;2:50-6.

21. IBGE. Instituto Brasileiro de Geografia e Estatística. Produção da Pecuária Municipal, 2016, Brasil. 2016. https://biblioteca.ibge.gov.br/visualizacao/ periodicos/84/ppm_2016_v44_br.pdf Acessed 10 Jan 2018.

22. CEPAGRI. Centro de Pesquisas Meteorológicas e Climáticas Aplicadas à Agricultura. Campinas: UNICAMP; 2017. http://www.cpa.unicamp.br. Accessed 14 Feb 2017

23. Astudillo VM. Encuestas por muestreo para estudios epidemiologicos en poblaciones animales. Rio de Janeiro: Centro Panamericano de Fiebre Aftosa, 1979. 60p. (Serie de Manuales Didacticos, 12).

24. Reed $L$, Muench HA. Simple method of estimating 50 per cent end point. Am J Hyg. 1938;27:493-7.

25. Van der Poel WH, Kramps JA, Middel WG, Van Oirschott JT, Brand A. Dynamics of bovine respiratory syncytial virus infections: a longitudinal epidemiological study in dairy herds. Arch Virol. 1993;133:309-21.

26. Ohlson A, Alenius S, Travén M, Emanuelson U. A longitudinal study of the dynamics of bovine corona virus and respiratory syncytial virus infections in dairy herds. Vet J. 2013;197:395-400.

27. Del Fava C, Pituco EM, D'Angelino JL. Herpesvirus bovino tipo 1 (HVB-1): revisão e situação atual no Brasil. Rev Educ Contin CRMV-SP. 2002;5:300-12.

28. Flores EF, Weiblen R, Vogel FSF, Roehe PM, Alfieri AA, Pituco EM. A infecção pelo vírus da diarreia viral bovina (BVDV) no Brasil - histórico, situação atual e perspectivas. Pesqui Vet Bras. 2005;25:125-34.

29. Liu L, Lehmkuhl HD, Kaeberle ML. Synergistic effects of bovine respiratory syncytial virus and noncytopathic bovine viral diarrhea virus infection on selected bovine alveolar macrophage functions. Can J Vet Res. 1999;63:41-8.

30. Loneragan GH, Thomson DU, Montgomery DL, Mason GL, Larson RL. Prevalence, outcome and health consequences associated with persistent infection with bovine viral diarrhoea virus in feedlot cattle. J Am Vet Med Assoc. 2005;226:595-601.

31. Flower FC, Weary DM. The effects of early separation on the dairy cow and calf. Anim Welf. 2003;12:339-48.

32. Wagenaar JP, Langhout J. Practical implications of increasing natural living through suckling systems in organic dairy calf rearing. NJAS Wagening J Life Sci. 2007;54:375-86

\section{Ready to submit your research? Choose BMC and benefit from:}

- fast, convenient online submission

- thorough peer review by experienced researchers in your field

- rapid publication on acceptance

- support for research data, including large and complex data types

- gold Open Access which fosters wider collaboration and increased citations

- maximum visibility for your research: over $100 \mathrm{M}$ website views per year

At BMC, research is always in progress.

Learn more biomedcentral.com/submissions 